\title{
Pedagogia do trabalho braçal e coletivo no porto de Porto Alegre (1961-1989)
}

Jairo Luis Fleck Falcão*

Resumo: Neste artigo, analisam-se alguns elementos das formas de organização do trabalho dos trabalhadores do porto de Porto Alegre, nos anos 60, 70 e 80 do século XX, focando as maneiras costumeiras como se dava o seu processo de ensino-aprendizagem, no fazer do trabalho, nas relações e inter-relações, no dia a dia. Ação de sujeitos na construção de sua história, que se denomina de Pedagogia do trabalho braçal e coletivo. As principais fontes empregadas são as narrativas produzidas por meio da interação entre entrevistado e entrevistador pelo registro da História Oral, fruto da experiência da coletividade dos trabalhadores do porto. Mesmo se tratando do registro de lembranças individuais, elas também representam sempre a coletividade na qual o narrador está inserido. Percebe-se, por essas narrativas, cotejadas com outras fontes, que os trabalhadores tinham uma forma peculiar de passar os conhecimentos para as futuras gerações, cuja base está na priorização dos elementos práticos, cotidianos e costumeiros. Essas construções foram fundamentais na constituição da experiência do trabalho e reforçaram a configuração das lutas dos trabalhadores do porto de Porto Alegre, representados pelos seus Sindicatos e Federações.

Palavras-chave: Trabalhadores Avulsos. Trabalho Braçal. Trabalho Coletivo. Ensino-Aprendizagem.

"Doutor em História e professor da Universidade do Estado de Mato Grosso (UNEMAT). E-mail: jairofalcao@unemat.br

Anos 90, Porto Alegre, v. 22, n. 42, p. 407-445, dez. 2015 


\section{Introdução}

Neste texto, discutem-se as ações de sujeitos no fazer de sua história, as formas de organização do trabalho pelos trabalhadores do porto de Porto Alegre, nos anos 60, 70 e 80 do século XX, princi-

$\infty$ palmente as maneiras costumeiras de inserção no trabalho, no fazer e no saber fazer, isto é, como se dava o ensino-aprendizagem dos trabalhadores, o que se denomina de pedagogia do trabalho braçal e coletivo.

As principais fontes utilizadas são as narrativas, produzidas por meio da interação entre entrevistado e entrevistador, pelo registro da História Oral, fruto da experiência da coletividade dos trabalhadores do porto, pois, mesmo sendo registro de lembranças individuais, sempre representam a coletividade na qual está inserido o narrador.

O Corpus Documental deste texto é composto por seis entrevistas realizadas pelo autor, por meio da Metodologia da História Oral. ${ }^{1}$ Conforme Camargo e Nunes (1977); Penna (2005); Constantino $(2004,2006)$ e Alberti (2010), considera-se a História Oral uma metodologia em que a principal fonte utilizada é a oral. Produzida pela interação entre entrevistador e entrevistado e previamente preparada por meio de um projeto de pesquisa e de um roteiro de entrevista, gravada seguindo técnicas de uso do gravador e de interação entre sujeitos, na qual o entrevistador procura tematizar aspectos realçadores da memória. A entrevista é transcrita conforme as palavras do entrevistado e depois é corrigida a ortografia, mantendo a essência das narrativas. Conforme Alberti (2010, p. 181) "[...] ajustar o texto às normas estabelecidas pelo projeto (maiúsculas $\mathrm{e}$ minúsculas, numerais, sinais como aspas, asteriscos etc.) e adequar a linguagem escrita ao discurso oral (esforço no qual a pontuação desempenha papel fundamental)".

Conforme Alberti (2004), cada entrevista é fruto da interação do entrevistado com o entrevistador e, por isso, tem uma especificidade: é o registro de um momento. A partir da provocação que faz o entrevistador, o entrevistado tem que dar conta de transformar lembranças, experiências, vivências e episódios em linguagem. A entrevista transforma-se em um documento; por isso, no depoimento, 
alguns elementos se cristalizam, participam da disputa da memória: "[...] emergência de sentido, ou produção versus interpretação de sentido", em que o entrevistado produz um novo sentido para um velho "dito popular", em que busca recursos para explicitar sua narrativa. A entrevista encerra histórias, em que se condensam, esteticamente, acontecimentos e sentidos; boas histórias não devem ser traduzidas por uma "moral", o significado está cristalizado na narrativa e, por isso, essas narrativas são citáveis. As entrevistas, que são produções de linguagem, estão crivadas de lembranças que caracterizam a memória individual e coletiva.

Para o historiador, a memória é suporte, pois se constitui em uma forma de conservar informações, "[...] reenviando-as, em um primeiro lugar, para um conjunto de funções psíquicas, graças às quais o homem pode atualizar impressões ou informações passadas, que ele representa como passadas" (LE GOFF, 1984, p. 11). Sendo assim, a concordar com Rousso (1996, p. 94), “[...] a memória é uma reconstrução psíquica e intelectual que acarreta de fato uma representação seletiva do passado, um passado que nunca é aquele do indivíduo somente, mas de um indivíduo inserido num contexto familiar, social, nacional". Quando se estuda a memória de um indivíduo, atribui-se a ele o peso de carregar a memória de um grupo, pois, como já falava Halbwachs (1990), ainda que seja uma produção individual do sujeito, a memória de cada indivíduo, ao mesmo tempo, funciona como representação de um coletivo.

Para Bergson (1990), a memória é um "instrumento" individual necessário para a sobrevivência do ser humano: é por meio da memória que nos movimentamos, recorremos aos amigos, executamos tarefas, saímos e voltamos para casa, repetimos tradições e rituais, vivemos o dia a dia etc., mas a memória também é imaginação, conjunto de imagens, e, portanto, representação. A memória, segundo Bergson (1990, p. 187), "tem por função primeira evocar todas as percepções passadas análogas a uma percepção presente, recordar-nos o que precedeu e o que seguiu, sugerindo-nos assim a decisão mais útil”. Porém, continua Bergson (1990), a memória não se resume somente a isso, pois, 
[...] ao captar numa intuição única momentos múltiplos da duração, ela nos libera do movimento de transcorrer das coisas, isto é, do ritmo da necessidade. Quanto mais ela puder condensar esses momentos num único, tanto mais sólida será a apreensão que nos proporcionará da matéria (Ibid., loc. cit.).

Partindo dessa premissa de que a memória condensa momentos, temos o fundamento de que ela está ligada ao tempo; nem sempre podemos considerar o instante inicial e o momento exato, quando se fala de memória, mas tudo se atualiza e passa a ser referência a partir do "aqui" e do "agora".

A memória, para Bergson (1990, p. 187-88), está vinculada ao indivíduo e à relação com as coisas e os outros seres, mas o corpo do indivíduo é o centro da ação, "[...] meu corpo com seus 'centros perceptivos'. Estes centros são estimulados, e tenho a representação das coisas. Por outro lado, supus que esses estímulos não podiam produzir nem traduzir minha percepção. Portanto ela se encontra fora deles".

Benito Schmidt (2006) expressa preocupação com a falta de uma maior discussão teórica em torno do uso de aparatos da memória e sua relação com a história. Uma das questões colocadas pelo historiador diz respeito à utilização de termos indiscriminadamente, sem um aprofundamento teórico. Conforme Schmidt (2006, p. 96), muitos autores usam “[...] noções de maneira um tanto quanto superficial, esvaziando-os de suas efetivas contribuições teórico-metodológicas muitas vezes mesclando-os de forma descuidada, sem considerar suas matrizes epistemológicas e os debates a elas relacionados”. Neste texto, utilizam-se teóricos da memória, relacionados à história ou não, que buscam suas referências em duas diferentes correntes, denominadas por Schmidt (2006) "matriz fenomenológica-hermenêutica-compreensiva" e de "sociológica-cientificista-nomotética”. Situando, na primeira, Henri Bergson e, na segunda, Maurice Halbwachs. No entanto, procura-se colocá-los para dialogar, tendo claro que em alguns pontos existe uma incompatibilidade entre ambos. 
A análise realizada por Bosi (2004, p. 53-54) sobre memória, comparando autores como Bergson e Halbwachs, esclarece essa discussão. Para a autora, em "[...] Bergson, o método introspectivo conduz a uma reflexão sobre a memória em si mesma, como subjetividade livre e conservação espiritual do passado, sem que lhe parecesse pertinente fazer intervir quadros condicionantes de teor social ou cultural". A memória colocada sob o ponto de vista do indivíduo, não sendo tratada como relacionada ao grupo, mas sim a uma relação entre a "[...] subjetividade pura (o espírito) e a pura exterioridade (a matéria). A primeira filia-se à memória; a segunda, à percepção", não tematiza os "sujeitos-que-lembram", e nem visualiza as "relações entre os sujeitos e as coisas lembradas; como estão ausentes os nexos interpessoais, falta, a rigor, um tratamento da memória como fenômeno social". Porém, Halbwachs já parte de um objeto diferente. Ele não investiga a memória em si, mas "os quadros sociais da memória”; por isso, a ênfase é dada ao grupo, ao social, às relações que constroem os indivíduos. Ao contrário de Bergson, para quem "o espírito conserva em si o passado na sua inteireza e autonomia", Halbwachs destaca "a iniciativa que a vida atual do sujeito toma ao desencadear o curso da memória. Se lembramos, é porque os outros, a situação presente, nos fazem lembrar [...]”. Portanto, o ato de lembrar não significa reviver aquilo que já passou, "[...] mas refazer, reconstruir, repensar, com imagens e ideias de hoje, as experiências do passado". (BOSI, 2004, p. 54)

Conforme esclarece Marluza Harres (2004, p. 145), “é a experiência do indivíduo com o passado que precisa ser compreendida, o que implica termos em conta o trabalho de memória na formação das identidades pessoais e sociais”. Dessa forma, a significação assumida pelo passado, em termos individuais - inserção social, interação social, tensão entre indivíduos e múltiplos constrangimentos sociais -, será analisada como um elo de entendimento das vivências e experiências dos trabalhadores do porto de Porto Alegre. 


\section{Trabalhadores avulsos e o porto de Porto Alegre}

No porto de Porto Alegre, os trabalhadores desenvolveram uma série de costumes, que mantiveram e consagraram, os quais os unificavam, apesar da dispersão dos sindicatos, e os mantinham como avulsos, frente às diversas tentativas de modernização e modificações das formas de contratação da mão de obra realizadas tanto pelo Estado quanto pelos empresários do transporte.

O que caracteriza as categorias avulsas, além do fato de trabalharem para diversas empresas, especialmente nos portos, é a dependência da movimentação de navios e mercadorias no porto para inserirem-se no trabalho; por isso, os sindicatos que os representavam acabaram constituindo dois quadros: o dos associados e do quadro-extra, também chamados bagrinhos. Foi, então, estabelecido pela Capitania dos Portos um limite de associados de acordo com a movimentação no porto, ficando, os outros, esporádicos, por isso, legalmente chamados de "força suplementar". Dessa forma, os sindicatos das categorias de avulsos dos portos se formaram e constituíram um sistema de organização do trabalho a partir das peculiaridades que assumiam nos portos e embarcadouros.

Eric Hobsbawm (1981) explica como surgiu na Inglaterra o que denomina de restricionismo e casualismo, mas também explica como os trabalhadores se posicionaram em defesa desse sistema em oposição à possibilidade de trabalho como empregado. O historiador inglês, ao analisar os trabalhadores do porto no que concerne à organização dos sindicatos de estivadores, especialmente na Inglaterra, evidencia a ocorrência de três problemas para quem pretendeu organizar o sindicato nas docas: "O primeiro era normal do sindicato de ofício: estabelecer e manter restrição na entrada para o ofício”. Dessa forma, deu-se a restrição para o ingresso, pois as "organizações de estivadores de ofício os estabeleceram rapidamente e asseguraram todas as vantagens da restrição, reconhecimento e profissão fechada que eles nunca mais iriam perder depois" (HOBSBAWM, 1981, p. 213-214).

O segundo problema, o dos não-habilitados, que para Hobsbawm (1981, p. 214), "não pode ser resolvido pelo restricionismo 
antiquado", pois, apesar de os economistas terem apontado "a ineficiência desconcertante do sistema de mão-de-obra casual”, e também o fato de que "alguns líderes sindicais pudessem ter apreciado as vantagens da descasualização de um ponto de vista de barganha" houve forte oposição, porque, explica Hobsbawm, "uma coisa era impedir novos homens de entrar para a profissão; outra completamente diferente era lançar Bill e Jack (e talvez a si mesmo) no olho da rua. Uma coisa era conseguir trabalho mais ou menos regular”, mas outra, bem diferente, era perder a preferência, ou "se tornar uma 'preferência B' permanente, condenado a trabalho menos regular e a menos dinheiro". Porém o que destaca Eric Hobsbawm (1981, p. 214) é que, quanto "mais pobre e casual o estivador, mais se apegava ele à justiça grosseira do casualismo, mesmo que esta fosse apenas a justiça da loteria, na qual qualquer um podia tirar o número da sorte”. Logo, podemos dizer que duas coisas pesavam nessas escolhas: a liberdade de escolher o dia em que iria trabalhar e o risco de não obter trabalho, como o próprio Hobsbawm relaciona anteriormente.

Um terceiro problema apontado por Hobsbawm (1981, p. 215) era o de "como impedir as seções 'fortes' de organizarem seus próprios sindicatos de quase-ofícios, deixando os 'fracos' à mercê do mercado, ou, falhando isto, como garantir a coordenação mais eficaz entre os vários tipos de sindicatos".

No caso do Brasil, na formação dos sindicatos de trabalhadores dos portos brasileiros, no início do século XX, alguns aspectos do restricionismo e do casualismo foram aqui implementados. Fernando Teixeira da Silva (2003, p. 170) diz que as características de diversos portos brasileiros era a "dispersão física e institucional de suas unidades”, sem existir uma centralização mediante um único órgão que coordenasse todas as atividades, pelas dificuldades encontradas em formar "um quadro de trabalhadores permanente". Dessa forma, cada grupo específico de trabalhador formava o seu sindicato isolado: "A independência de cada um deles na fixação de diferentes normas de contratação dificultava a existência de acordos unificados para limitar a concorrência entre trabalhadores e criar solidariedade contra os patrões”. 
Além disso, os armadores, para aumentar seus lucros, buscavam concorrência entre os grupos de trabalhadores, que, na maioria das vezes, ficavam nas mãos de empreiteiros, que competiam entre si, diminuindo salários e aumentando a exploração da mão de obra. No entanto, segundo Silva (2003, p. 171), "as atividades realizadas em ternos ${ }^{2}$ permitiam contatos e conversas regulares entre seus componentes, possibilitando a resistência à exploração e aos caprichos dos contramestres”. Como a preocupação dos armadores sempre foi a permanência dos navios no cais, os estivadores tinham armas poderosas, a paralisação e a redução do trabalho, e souberam aproveitar-se disso e forçar negociações. Todavia, a preocupação com o tempo parado e as táticas de luta dos estivadores fazia com que os armadores aumentassem a jornada de trabalho, ultrapassando o limite regulamentar, o que gerava extraordinários aos trabalhadores. Portanto, essa tática dos trabalhadores era mais eficiente do que grandes paralisações.

Quanto às formas de contratação no porto de Porto Alegre, na década de 1930, segundo Silva (2003, p. 170), a empresa armadora Lloyd Brasileiro contratava "por intermédio de sua agência no Porto, estivadores mensalistas e diaristas engajados, quando necessários", a chamada "estiva direta". As empresas armadoras Companhia Nacional de Navegação Costeira, Lloyd Nacional S.A., Companhia de Comércio e Navegação e Companhia Carbonífera Sul Rio-Grandense "[...] tinham sua estiva contratada por empreiteiros que se obrigavam a agir como contratantes de mão de obra, pagando as despesas relativas a taxas portuárias e eventuais avarias”.

O processo de instituição da closed $s h o p^{3}$, conquistado pelos estivadores de Santos, nos anos 1930, descrita e analisada por Silva (2003), deixou as marcas na história da categoria de estivadores nos anos posteriores. Apesar de o Rio de Janeiro ter conquistado o controle do trabalho anterior a Santos, o peculiar no porto santista é o fato de ter sido uma disputa com uma companhia que já dominava a contratação e a realização dos serviços de carga e descarga no porto, bem como a sua administração, a Companhia Docas de Santos. Essa empresa, inclusive, fazia um jogo político e de interesse quando ocorriam greves no porto. Dessa forma, os 
estivadores obtiveram ganhos políticos consideráveis e souberam jogar com a força do Estado e de seu discurso de compromissos entre as classes e conseguiram, de certa forma, transforma em lei suas reivindicações e conquistas, universalizando-as, dessa forma, a todos os outros portos organizados do Brasil, não descartando, também, a contribuição dos trabalhadores dos outros portos brasileiros.

Para Ingrid Sarti (1981, p. 37), o Estado exerceu um controle sobre o sindicato estivador, "[...] de forma umbilical através de uma cuidadosa legislação que lhe dedica trinta capítulos”. Por outro lado, Fernando da Silva (2003) propõe outra leitura, a de que a legislação que acabou gerando a CLT é fruto de lutas e disputas e, em grande parte, "[...] da condensação de uma longa história de lutas dos estivadores e de conquistas alcançadas antes mesmo de sua formulação". Ao longo do tempo, os trabalhadores dos diversos portos foram se apropriando desses discursos legislativos e, juntamente com as suas lutas locais, fizeram valer os seus direitos, mantendo a exclusividade na contratação do trabalho de estiva por meio do sindicato.

Em 1919, foi criada a União dos Operários Estivadores de Porto Alegre, uma sucursal do Rio de Janeiro, que, nos anos trinta, tornou-se o Sindicato dos Estivadores de Porto Alegre. Edgar Ávila Gandra (2004), ao analisar a organização do sindicato dos trabalhadores de capatazia do porto de Porto Alegre, demonstra a importância de constituir uma instituição de classe para esses trabalhadores, pois assim, eles obtiveram direitos fundamentais, que lhes eram negados anteriormente. Com o sindicato, veio o reconhecimento dos portuários como uma categoria dentro do porto, frente à Administração, e um consequente acordo coletivo em 1960, que os deixou em melhores condições tanto para lutar por mais direitos quanto para exercer a profissão com dignidade.

Diego Vivian (2008) demonstrou a ambiguidade das transgressões nos portos de Porto Alegre e Rio Grande e o uso das mesmas para justificar a existência de trabalhadores para vigiar outros. A importância da organização sindical e da conquista da reserva de mercado de trabalho possibilitou aos vigias portuários do Rio Grande do Sul reivindicar direitos e controlar quem poderia trabalhar, o tempo e as condições desse trabalho. 
Por conseguinte, o sindicato simbolizava para o trabalhador muito mais do que a representatividade perante os patrões. Era a organização do trabalho, a possibilidade de trabalhar, mas também o alvo mais próximo de reclamação e diálogo. Para muitos, era o intermediador, o elo de reconhecimento perante a comunidade em geral, mas, sobretudo, o referencial de manutenção dos costumes, dos rituais, da união e do respeito entre os trabalhadores, o representante, o referendador. Finalmente, o sindicato era o executor das relações de poder entre os associados, o quadro-extra e os outros avulsos. Pode-se dizer que cada um dos sindicatos de avulsos tinha estrutura e organização diferente, adotada pela experiência de cada categoria, que o fundou, mas ambos tinham, para os trabalhadores, as finalidades descritas anteriormente.

Nos anos 60 e 70, o porto de Porto Alegre era um caleidoscópio de pessoas, mercadorias, máquinas e navios ancorados, saindo e entrando nos três cais. Era um coração pulsando e bombeando suas artérias para todos os lados. Era gente indo e vindo na dispersão e na integração, quando a capital era invadida pelo porto e integrada a ele. Hoje, a realidade é desoladora, fala-se em revitalização, e não reativação, objetivos concretos para ocupar o espaço e modernizar a orla, mas não para resolver o problema do porto e dinamizar o transporte. Nas figuras 1, 2 e 3, pode-se ver como está estruturado, atualmente, o porto de porto Alegre. Conforme informações da Superintendência de Portos e Hidrovias (SPH), este possui um cais acostável, com extensão de $8.028 \mathrm{~m}$, subdividido em três trechos: Cais Mauá, Cais Navegantes e Cais Marcílio Dias. Conforme consta no site do SPH: "Sua estrutura envolve 25 armazéns com $70 \mathrm{mil} \mathrm{m}^{2}$, numa área total de $450 \mathrm{mil} \mathrm{m}^{2}$. Desde o primeiro semestre de 2005, a área de operação do porto público está concentrada no cais Navegantes [...]”. 
Figura 1 - Cais Mauá

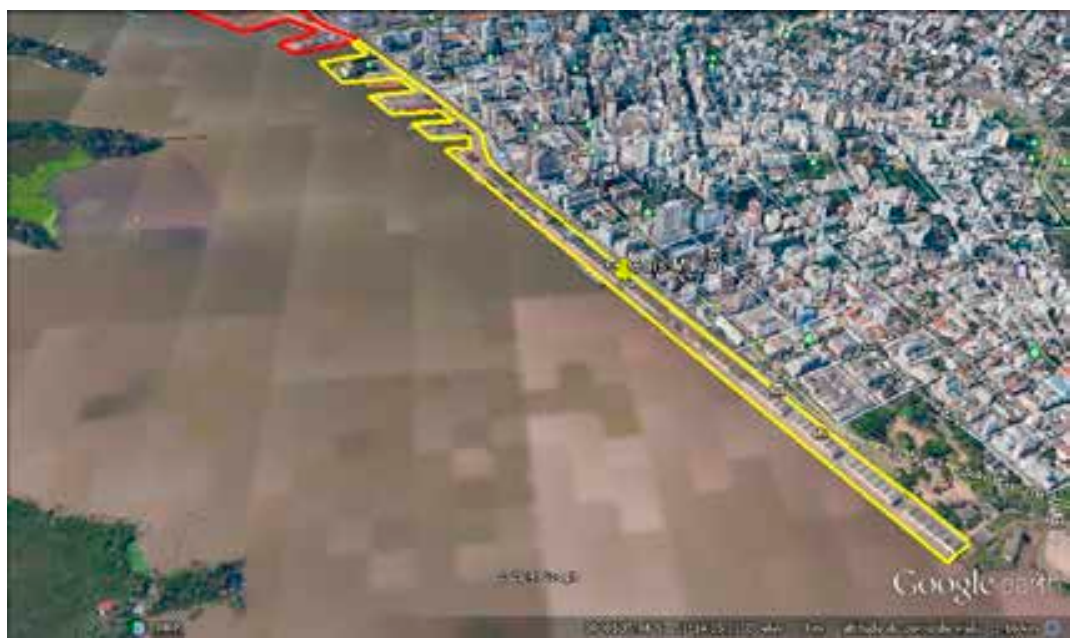

Fonte: <http://www.sph.rs.gov.br/sph_2006/content/img/cais_maua.jpeg>. Acesso em: 19/12/2015

Conforme informações da $\mathrm{SPH}^{5}$, o Cais Mauá possui $3.240 \mathrm{~m}$ de comprimento, contendo 16 berços, ${ }^{6}$ com profundidade variando entre $4 \mathrm{~m}$ a 5,5 $\mathrm{m}$. Nesse cais, eram realizada a carga e descarga de mercadoria geral - madeira, cereais, farelo de trigo, adubo, soda e alimentos em geral - por meio da navegação de longo curso, de cabotagem e interior. O cais Mauá possui, em sua extensão, "[...] 18 armazéns, dos quais 12 são para carga geral, totalizando $20.178 \mathrm{~m}^{2}$, e os demais seis com utilizações diversas. Os pátios, em número de quatro, perfazem $2.180 \mathrm{~m}^{2}$ ". Atualmente, encontra-se arrendado para a revitalização, "[...] visando transformá-lo em área de turismo, serviços, lazer e de preservação do patrimônio histórico, cultural e arquitetônico do Porto de Porto Alegre"7.

O Cais Navegante (figura 2) tem profundidade de $6 \mathrm{~m}$ de calado $^{8}$, com extensão de $3.268 \mathrm{~m}$, "[...] dispõe de 12 berços, com 11 armazéns, sendo seis para carga geral e cinco para granéis sólidos, somando as áreas, respectivamente, $23.880 \mathrm{~m}^{2}$ e $16.320 \mathrm{~m}^{2 ”}$. 


\section{Figura 2 - Cais Navegantes}

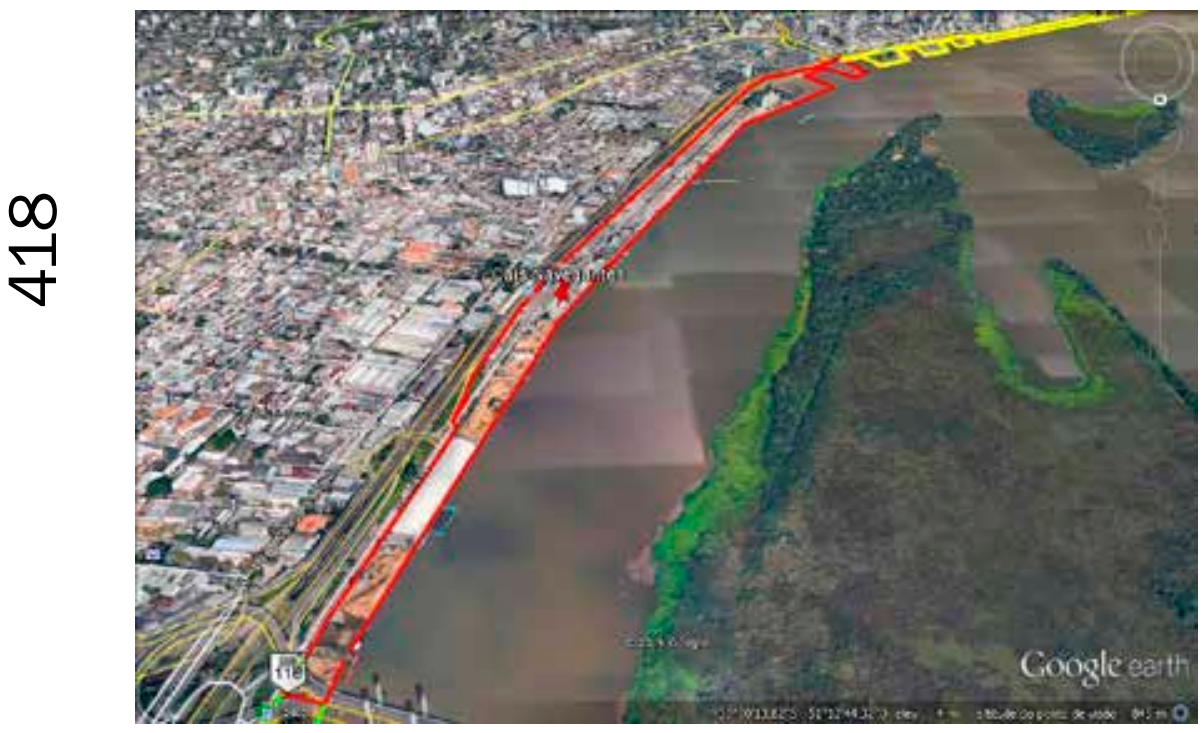

Fonte: 〈http://www.sph.rs.gov.br/sph_2006/content/img/cais_navegantes.jpeg> Acesso em: 19/12/2015.

O Cais Marcílio Dias (figura 3), com profundidade variada entre 4 e 5 metros, possui uma extensão de $1.366 \mathrm{~m}$ de comprimento. Os cinco berços servem "[...] à movimentação de areias e seixos rolados”. Em toda a extensão do cais, existem cinco pátios descobertos, servindo o maior, com $36.105 \mathrm{~m}^{2}$, para acondicionamento do carvão "e os demais totalizando $22.340 \mathrm{~m}^{2}$ "”. 


\section{Figura 3 - Cais Marcílio Dias}

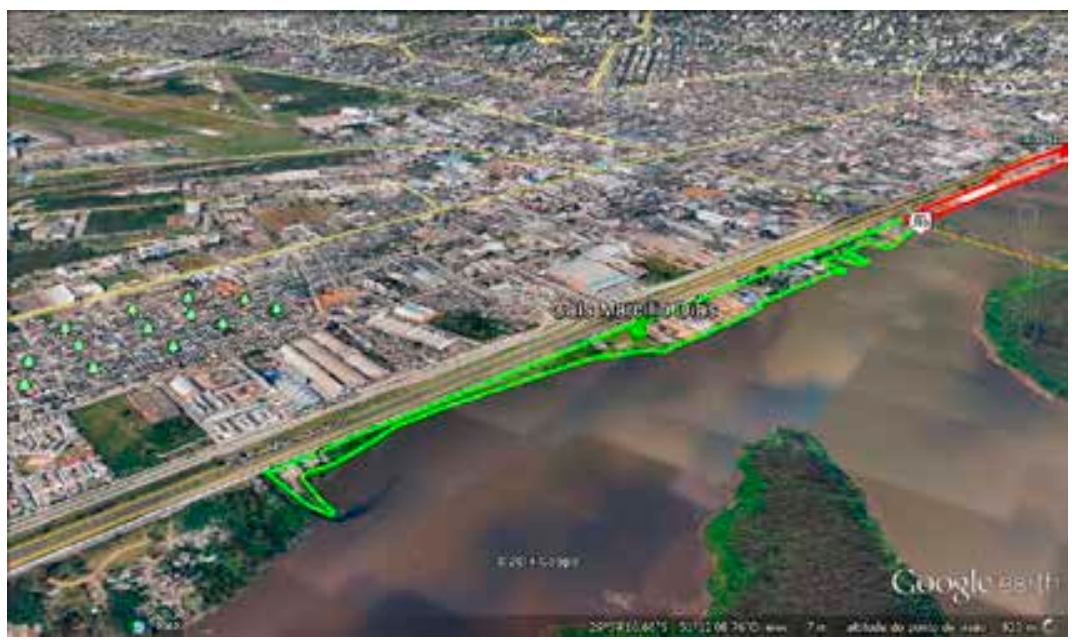

Fonte: 〈http://www.sph.rs.gov.br/sph_2006/content/img/cais_navegantes.jpeg> Acesso em: 19/12/2015.

\section{Pedagogia dos trabalhadores do porto}

Segundo Alexandre Fortes (1995, p. 105), em Thompson, tem-se o uso do termo costume "[...] preferencialmente à tradição ou cultura popular. Busca-se, assim, evitar tanto a ideia de permanência que tende a ser associada à primeira quanto a visão de sistema ordenado (e mesmo de consenso) sugerido pela segunda". Portanto, para Thompson,

[...] longe de exibir a permanência sugerida pela palavra "tradição", o costume era um campo em mudanças e a disputa, uma arena na qual interesses opostos apresentavam reivindicações conflitantes. Essa é uma razão pela qual precisamos ter cuidado quanto a generalizações como “cultura popular”. Esta pode sugerir, numa inflexão antropológica influente no âmbito dos historiadores sociais, uma perspectiva ultraconsensual dessa cultura, entendida como 
"sistema de atitudes, valores e significados compartilhados, e as formas simbólicas (desempenho e artefatos) em que se acham incorporados". Mas uma cultura é também um conjunto de diferentes recursos, em que há sempre uma troca entre o escrito e o oral, o dominante e o subordinado, a aldeia e a metrópole; é uma arena de elementos conflitivos, que somente sob pressão imperiosa - por exemplo, o nacionalismo, a consciência de classe ou a ortodoxia religiosa predominante - assume a forma de um "sistema". E na verdade o próprio termo "cultura”, com sua invocação confortável de um consenso, pode distrair nossa atenção das contradições sociais e culturais, das fraturas e oposições existentes dentro do conjunto (1998, p. 17).

Muitas ações de solidariedade costumeiras dos trabalhadores do porto ajudaram na manutenção do trabalho e na organização tanto para o desenvolvimento do trabalho quanto para a resistência e a busca e manutenção de direitos. Os trabalhadores do porto carregam essa experiência desde muito tempo e, através dos sindicatos de avulsos, das Federações ou da união entre os sindicatos e categorias, alcançaram objetivos comuns. Portanto, para alcançar seus objetivos, foi fundamental uma pedagogia da coletividade sobre o indivíduo que se inseria no trabalho, ao mesmo tempo em que se procurava manter formas de trabalho adquiridas na prática. Sendo assim, o trabalho gerava formas de aprendizagens que levavam os trabalhadores a solucionar seus problemas de uma maneira própria, com ações diferenciais na hora do trabalho, o que possibilitava maior agilidade. As técnicas costumeiras eram mobilizadas, ensinadas e aprendidas pelos trabalhadores no fazer.

No relato de Jorge Paiva ${ }^{10}$, que ingressou no porto em 1968, como bagrinho dos arrumadores, temos um exemplo de como se dava a aprendizagem na prática. Diz o entrevistado,

[...] quando cheguei lá, não sabia como seria o trabalho, era para o armazém C2, [...] era por chamada, aí peguei uma carteirinha, que chamavam na época de bagrinho, o pessoal quadro-extra. Ia sair a chamada, primeiro para os sócios de estiva [...]. O serviço para o pessoal do quadro, 
a parte melhor era para eles, e a pior sobrava para nós, do quadro-extra. Ali, conforme o desenvolvimento do serviço, a gente ia conhecendo pessoas e como era o serviço.

Conforme Thompson (1998, pp. 17-18), “o aprendizado, [...] também serve como mecanismo de transmissão entre gerações”, no caso dos trabalhadores do porto, de novos que ingressavam como bagrinhos. Todo o trabalho possui maneiras que possibilitam agilizar ou não a produção, dependendo dos seus próprios interesses. Porém, como a maior parte da carga e descarga era por produção, os trabalhadores tinham técnicas costumeiras para um melhor aproveitamento, aumentando a produção e diminuindo o esforço físico.

De acordo com Tiriba (2001, p. 183), “[...] na cooperação, a força coletiva difere da soma das capacidades dos trabalhadores isolados, transformando-se em nova força coletiva”; pode-se dizer que a produção da carga e descarga utilizando ternos de 2, 4 ou 6 pessoas era maior que a produção de cada indivíduo, se trabalhasse isoladamente. Porém, esse processo se dava pelas formas de atuação coletiva, que pressupõe técnicas e ações costumeiras para fazer com que o trabalho fosse executado com menor dispêndio de energia e mais agilidade, aumentando a produção.

Essas formas coletivas deveriam ser aprendidas pelo trabalhador, individual e coletivamente; logo, pode-se dizer que existia uma aprendizagem, denominada de pedagogia do trabalho coletivo, pois, conforme Tiriba (2001, p. 188), a educação não se limita aos muros escolares, mas vai além, "[...] invadindo todos os processos que envolvam a formação da consciência e a produção de subjetividade".

A primeira questão que se pode levantar é a da cooperação no trabalho. Jorge Paiva, em entrevista ao autor, relata como era necessária a ajuda de todas as categorias para executar o trabalho e do grupo de trabalhadores que formavam o terno. Sobre isso, ele afirma: "[...] tinha suas desavenças, o que é natural, cada um vem de uma etnia, todas as raças, mas terminava dando certo, de uma forma ou de outra, porque um sabia que precisava do braço do outro, a gente não estava sozinho. A gente não podia brincar de ilha, ninguém é uma ilha...”. 
A ideia de que se precisa do outro era uma aprendizagem constante e a forma de ensinar isso para o indivíduo que ainda não estava comprometido com essa proposta era bastante dura, mas, na linguagem dos trabalhadores, era aceita e pactuada. Segundo João Albino, popular Maromba ${ }^{11}$, em entrevista ao autor: "[...] não tinha essa de amarrar trabalho, porque, se amarrar trabalho, os caras cortam, sem dó nem piedade", porque o trabalhador que fazia o chamado "corpo mole" não ficava muito tempo no serviço. É o que segue dizendo o entrevistado, citando um exemplo de serviço a pá:

[...] tu estás dando dez pazadas, o outro uma. Chega o contramestre e diz:

- o que é camarada? O que houve? Estás doente?

- Não! Por quê? Estou fazendo o meu!

- Não, senhor! Os caras estão trabalhando e tu aí chupando sangue. Não vou te falar outra vez! Ouviu!

Volta lá e o cara está na mesma situação. Nem fala mais nada, vai lá fora na praça e busca outro para o lugar dele. Chega lá e diz:

- Epa! No lugar daquele lá. Sobe, nego, está cortado.

Segundo Jorge Paiva, em entrevista ao autor, outro forte motivo para se cortar o trabalhador do serviço era a embriaguez, pois não se tinha alternativa. É o que ele relata: "[...] apenas algum colega é substituído, ou, por problema de doença ou, a maior parte, por embriaguez. Era perigoso... teve gente morrendo... rebentou a lingada, matou o cara lá embaixo, uma caçamba matou... teve muita gente que faleceu ali dentro". Como o trabalho era executado por bagrinhos, com a fiscalização do contramestre, sempre se tinha a preocupação com a prevenção, tanto que o álcool era proibido no ponto de estiva. Porém, conforme Jorge Paiva, por ser "[...] serviço pesado, perigoso e o pessoal alcoolizado, aí não tem como. Muita coisa acontecia. Claro que não saía para rua assim, [...] é o que se viveu. Muita gente até hoje ficou aleijado". Já Maromba, em sua entrevista diz que todos se ajudavam no trabalho, era uma coletividade, mas, quando aparecia algum trabalhador que destoava dos demais, era comunicado duas ou três vezes, mas, se não adiantasse, a ação era violenta. Relata o entrevistado: 
[...] para o vagabundo, quem não trabalhava, se dava o aviso: - larga, porque é bom para tua saúde, meu! Daqui a pouco vai quebrar um pé, vai quebrar um dedo, vai quebrar a canela [...]. Não vai meter a mão aí, rapaz? O quê! Tu vais ficar me chupando o dia todo?

Daqui a pouco chama a atenção de novo. $\mathrm{Na}$ terceira ou quarta, wap! Vap! ela passa só por cima, e pega a canela...

- Ouch! Ai! Ai! Ai! Ai! Um ferro me bateu...

- Olha, companheiro desculpa... Arruma uma maca aí, arruma.

Isso é sem dó e sem piedade, porque ele está fazendo pior comigo, ele tem condições de trabalho e não está me respeitando, e, amanhã o dinheiro é o mesmo. Isso é violento. Pode ser. Mas ele está usando da maneira violenta também, só, que é light, é camuflada. Então, não sai por bem, sai por mal, entendeu como são as coisas. Funciona assim.

Por outro lado, conforme o próprio Maromba, "o estivador é um expert em evitar um acidente de trabalho", pois ia aprendendo, na prática, técnicas de segurança e, por isso, muitas vezes impedia acidentes, "agora mesmo [...] eu ia dar um passo atrás, mas bati e parei. É uma coisa gozada. Tu pegas o jeito. Trabalhas num buraco de trinta metros pra cá, todo o tempo ali, mas não podes ficar naquele buraco, nunca, mas tu tens a noção da distância". As técnicas eram próprias do trabalho, diferente de qualquer outra empresa, algo que não se aprende na faculdade ou em curso técnico fora do local de trabalho, "[...] não tem como o próprio estivador, para falar de acidente de estiva e de porto. Não tem técnico em segurança, não existe técnico de segurança que venha falar, como evitar acidente de estiva, porque é outra coisa diferente, é outro mundo diferente". No entanto, por mais que adotassem medidas de segurança, ou que a prática lhes facultasse formas de aprendizagem, transmitidas aos colegas e aprendizes do ofício, acidentes aconteciam. Conforme explica Maromba, "[...] onde tem muito trabalho e o serviço é perigoso, os acidentes acontecem, ou por imprudência, ou por falha mecânica, mas a maioria dos acidentes que eu presenciei, no decorrer desses trinta e poucos anos, foi por imprudência do próprio acidentado". 
Entretanto, os trabalhadores do porto, de forma autogestionária, faziam um trabalho pedagógico com os aprendizes do ofício e com os próprios colegas, na medida em que se inseriam e se relacionavam com outros trabalhadores realizando o processo produtivo de forma a contemplar os interesses coletivos da categoria, pois, ao ter a closed shop, as categorias de avulsos do porto organizado possuíam o controle de todo o processo produtivo e, também, da administração do sindicato.

As categorias avulsas se caracterizam por não estabelecer vínculos empregatícios com nenhuma companhia de navegação específica, “operários sem patrões”, que deram título ao livro de Fernando Teixeira da Silva (2003), que analisa os trabalhadores de Santos no entreguerras, destacando os estivadores, que conseguiram a "[...] closed shop, ou seja, deter o controle do mercado de trabalho através do sindicato dos estivadores" (SILVA, 2003, p. 194).

No dizer de Maromba, "[...] o estivador não tem patrão; ele só tem patrão quando ele se emprega às sete horas da manhã, por uma companhia ' $\mathrm{X}$ ', e então ele é empregado daquela companhia no período em que ele estiver trabalhando". Porém, como lembra outro entrevistado, Eduardo Rech" ${ }^{12}$, era "[...] o sindicato quem dirigia o trabalho, os conferentes, exercendo várias funções como está previsto. Então, o sindicato escalava, o sindicato cobrava e o sindicato pagava”.

Assim como os estivadores, os conferentes de carga e descarga também eram trabalhadores avulsos, que prestavam serviço dentro dos portos organizados. Nos anos sessenta, foi normatizada a profissão de Conferente de Carga e Descarga, como trabalhador avulso que participava do sistema rodiziário ${ }^{13}$. Portanto, faziam parte do rodízio: o conferente chefe, conferente ajudante, conferente de porta ou lingada e conferente de rendição, conferentes de manifesto, balança ou avaria.

De acordo com as diversas operações de carga e descarga, os trabalhadores se inseriam no trabalho conforme solicitação dentro dos ternos, obedecendo à organização do seu sindicato, por meio do sistema rodiziário.

Maromba, que foi vice-presidente do Sindicato dos Estivadores e que, em um determinado período, teve a incumbência de fazer 
a escala de serviço, conta como era realizada a distribuição, que dependia da qualidade da carga. Diz o entrevistado:

[...] são cinco escalas até chegar no granel, e mais uma que, a gente diz, vai de qualquer jeito. É quando dá só a diária [...] as chamadas ricas, por exemplo, bobina de papel, [...] dá uma remuneração maior; então, tendo uma chamada, se diz: essa é estrangeira. Outra, parecida, bobina de aço, um pouco menor a tarifa, sai na [...] nacional. Outra de remuneração menor, a vista.

Quanto ao horário das chamadas, em geral, eram realizadas três por dia, como relata Jorge Paiva: "tem chamada às sete, tem chamada à meia hora, depois tem de noite, seis e meia, quinze para sete". Mas, dependendo da quantidade de serviço, poderia ter mais horários de chamadas. $\mathrm{O}$ ponto de chamada da estiva ficava na frente da antiga sede, onde atualmente é a Delegacia Regional do Trabalho (DRT), mas chegou a ter, nos anos sessenta e setenta, mais outro ponto no cais Navegantes, denominado pelos trabalhadores de coreia.

Já a chamada dos conferentes era diferente, até porque o número de trabalhadores era bem menor: reuniam-se três vezes ao dia e faziam a distribuição do serviço conforme o rodízio, o que também ocorria no caso das chefias; além disso, faziam a escalação por ganho. Esta constatação depreende da análise da Ata da Assembleia Geral, no 92, 04.02.1965 do Sindicato dos Conferentes de Carga e Descarga do Rio Grande do Sul. A prática de fazer o rodízio na distribuição do trabalho mais a escalação por ganho funcionou a partir de 1964 e o sindicato controlava os ganhos de cada trabalhador do quadro por meio de uma planilha, fazendo a distribuição de forma que cada um passasse por todos os tipos de escalas (Chefias, Majoradas, Porta, Lingada e Rendição), havendo um número específico de escalação. Esse sistema dava uma igualdade no salário final de todos os trabalhadores do quadro, à exceção daqueles do quadro-extra. Essa questão gerou divisão e disputas dentro da categoria de trabalhadores conferentes de carga e descarga, visto que a escalação por ganho, adotada a partir de agosto de 1964, 
feria os interesses de alguns trabalhadores. Mas, apesar de ter sido decidido pela assembleia, eles estavam descontentes com a forma como vinha sendo realizada a distribuição, e, na oportunidade que teve, esse grupo denunciou as irregularidades ao Delegado da Delegacia do Trabalho Marítimo (DTM) ${ }^{14}$, com o objetivo de tirar algum proveito. Porém, após a participação de um representante da DTM na Assembleia e na discussão sobre a Escalação por ganho, o Regimento que mantinha o rodízio na distribuição do trabalho e a escalação por ganho foi aprovado e acatado pela DTM ${ }^{15}$.

Essa situação lembra o casualismo que Hobsbawm (1981, p. 214) enunciou como um problema a ser enfrentado pelos trabalhadores, porém, para um grupo, era motivo de apego e orgulho: "mais se apegava ele à justiça grosseira do casualismo", o que seria como a sorte da loteria. Contudo, essa questão estava sendo resolvida pelo sindicato dos conferentes em carga e descarga dos portos do Rio Grande do Sul, em Porto Alegre, exatamente sob a ditadura civilmilitar. Por outro lado, a dimensão do casualismo era a questão da liberdade e do ócio, pois, ganhando um bom dinheiro em determinado momento, quando pegava um trabalho bom, poderia ficar em casa descansando, sem trabalhar, bebendo, fazendo "festa" e não tendo a necessidade de labutar todos os dias.

Essa situação, citada anteriormente, denota a questão da oposição entre "sorte e regulação do ganho", representada pela dupla escalação por número (carteira de sócio no sindicato) versus escalação por ganho. Essa questão foi muito debatida pelos trabalhadores do porto de Porto Alegre e mesmo por trabalhadores de outros portos, certamente. Fernando Teixeira da Silva (2003) fala da pacificação da estiva, quando os estivadores do porto de Santos adotaram o sistema de rodízio, que pretendia disciplinar aquelas situações de privilégios com ganhos maiores, a formação de gangos ${ }^{16}$ e o favorecimento pelos contramestres, e das escolhas de serviços cujo ganho era maior. Todavia, por meio do rodízio, possibilitava a disputa por melhores colocações, o que dependia da sorte e de ficar de olho na distribuição do serviço, mas ainda não igualava os ganhos. Porém, com o tempo, os trabalhadores foram aperfeiçoando o sistema de rodízio procurando disciplinar tais distorções, inclusive para diminuir brigas, desavenças e disputas. $\mathrm{O}$ exemplo citado dos conferentes 
de carga e descarga de Porto Alegre ilustra essa questão, porque eles resolveram o problema da distribuição disciplinando os ganhos de cada trabalhador e fazendo a escalação de acordo com esse ganho.

Quanto à organização das chamadas, na estiva, primeiro eram escolhidas as chefias e, depois, os trabalhadores braçais. Conforme Maromba, "as chamadas de estiva são: primeiro era o contramestre geral, que é o capataz, contramestre de porão, que é contramestre, [...] depois, os trabalhadores de guindaste ${ }^{17}$, operador de empilhadeira, trabalhador de porão, trabalho braçal”. Quanto às chefias, só mudava o número do contramestre de porão, porque dependia da quantidade dos porões do navio em que teriam de trabalhar, já que era um contramestre por porão. Havia ainda os trabalhadores do guincho. São dois guincheiros, porque "[...] não pode estar cansado no guincho, tem que ter responsabilidade, tanto com o trabalhador que está no porão quanto com a carga; então, são dois e eles fazem rodízio, duas horas pra cada um, vai lá, descansa, toma uma água, volta". E acrescenta: "[...] o sinaleiro é o que faz o sinal para o guincheiro, porque o guincheiro, na maioria das vezes, não enxerga o porão do navio; então, tem o camarada que faz o sinal: também são dois". O sinaleiro, também chamado de portaló, era o estivador que fazia a comunicação entre o porão, o guindasteiro e o guincheiro. $\mathrm{O}$ guindasteiro trabalhava no lado de fora do navio e pertencia à capatazia do porto, mas, quando a bordo, nos guindastes da embarcação, era estivador.

Maromba, a respeito da época em que era Fiscal Geral do Sindicato e fazia a escalação, diz que mantinha as duas escalações e dá o exemplo de como fazia quando a escala era a de bagrinhos. Era necessário escalar ao menos um homem experiente para executar o trabalho no porão.

[...] às vezes deixava uma vaga para o contramestre, porque o contramestre tem um cara de confiança dele, que é o camarada que é safo no trabalho, se tu vais botar lá embaixo do porão, porque ele vai ser uma liderança, fala a mesma língua dos bagrinhos, porque tem aí uma certa inimizade, entre o bagrinho e o associado, ela é cega, é muda, e, se 
tem um camarada chave que põe lá embaixo, resolve o teu problema, o contramestre não se envolve muito, e o serviço anda, porque tudo é produção.

Esse fragmento da fala de Maromba traz à tona três elementos fundamentais na relação trabalhadores sindicalizados e bagrinhos na construção de uma imagem da categoria frente aos usuários. Primeiro, a compreensão de que os trabalhadores sobrevivem da produção e, mesmo que muitos trabalhos pagassem apenas a diária, precisavam ser executados, em prol do bem coletivo. Segundo, a noção de que os trabalhadores bagrinhos, iniciantes no serviço de estiva, poderiam boicotar o trabalho, mesmo que corressem o risco de serem cortados, o que seria desgastante para o contramestre, pois caso houvesse problema com um grupo inteiro de trabalhadores, seria diferente do que ter problema com apenas um. E, por fim, para evitar os problemas quanto à inserção e possibilidade de boicote, colocava-se uma liderança, bagrinho, um homem de confiança do contramestre, mas, sobretudo, "safo no trabalho". Essas questões são derivadas da experiência que o próprio trabalhador adquiriu na prática e da relação que tinha com o pai, o Maromba pai, que foi estivador, vice-presidente e presidente do sindicato dos estivadores de Porto Alegre, segundo relato de Maromba (filho).

Como o meu pai também foi fiscal geral por muito tempo, foi presidente, eu ouvia as conversas dele. O negócio é endurece com os brabos e não dar colher de chá para os compadres.

- Olha fulano! Ei! Psiu! Oh! Companheiro, vai deixar tirar o trabalho.

É o brabo.

- Blá... Blá... Blá! Blá! Preé! Preeeé...!

Aquela gritaria e coisa...

- o que é, está pensando o que cara!

- Aí, companheiro. Não vou falar de novo contigo.

Ele: - Ah! É? (Em tom de ironia);

- Não trabalha hoje;

E vou fazendo a chamada: 
- 37, 38, 40;

E ele:

- Blá... Blá... Blá...

- Três dias; 50, 55...

E eu estou pegando carteira,

-60 .

E ele:

- Blá... Blá... Blá...

- Dez dias pra ti, companheiro.

- Blá... Blá... Blá...

- Quinze dias para ti, companheiro.

Aí... Porque quinze dias é um prejuízo muito grande e não tem santo que tire ele daqueles quinze dias. Aí, ele promete coisas.

- Vou te meter um tijolo! Vou te meter uma pedra...

- Tu faz bem feito, nego! Tudo o que tu pode fazer para mim, eu posso fazer em ti também. Tu faz bem feito o teu trabalho aí, porque, quando eu saí daqui, tu estás complicado.

Desse fragmento da entrevista com Maromba, derivam três questões bastante importantes para se pensar uma pedagogia coletiva: a) a existência de regras: há um regulamento pactuado por todos os trabalhadores e elaborado pela assembleia. Segundo o entrevistado, "[...] a estiva se punia, um pouco paternalista, pra o meu gosto; eu era mais radical, acho que o camarada merece uma oportunidade ou duas e, depois, bota prá rua o vagabundo, [...] a estiva podia dar gancho de trinta dias só, ou até a exclusão”; b) uma prática de ações enérgicas com relação aos trabalhadores destoantes, que, apesar de parecerem autoritárias, ocorrem na gestão de um momento crucial para todos os trabalhadores, a escalação. Conforme analisado por Falcão (2009), este era um espaço ritualizado e sagrado para os trabalhadores e, por isso, devia ter regras pactuadas e assumidas responsavelmente pelo escalador, como se ele fosse um árbitro que devesse julgar, no momento, as ações e, ao mesmo tempo, distribuir, de maneira equitativa, o trabalho, seguindo regras; c) a fala de Maromba, bem no início do fragmento, quando ele diz que sua ação era "endurecer com os brabos e não dar colher de chá para os 
compadres", apresenta uma forma de agir que deriva da experiência e se compõe em uma pedagogia da identificação dos indivíduos que são lideranças em potencial, o que identifica como "brabos" e os "compadres", ou os puxa-sacos, que se acham sob a proteção do líder, que, conforme Maromba:

E outra, aquele teu irmão, que tu tens, o teu irmão mesmo, aquele teu amigo, às vezes tu tens irmão que não é muito irmão, ele é meio prevalecido, se prevalece que está o amigão dele mandando, e faz as porcarias pensando que o cara vai passar a mão por cima. Eu adotei uma coisa diferente, se eu pegar tomando um gole de cachaça dentro do ponto de distribuição do trabalho, era três dias de gancho, o meu irmão, ele tomava cinco, entendeu como é que era. Tomava dobrado, quase que dobrado.

- Mas, porra Maromba, tu dá três dia pra os outros...

- Pois é, mas tu és safado, tu sabes que não podes beber, que sou eu que estou mandando, pensastes que eu, ao te ver bebendo, iria olhar para outro lado. Estás te prevalecendo de nossa amizade para fazer esse tipo de coisa, não estás sendo meu amigo. E se não estás sendo meu amigo, vai tomar cinco, toma quietinho, porque se sabes, que se colocares qualquer coisa na cabeça, vou aumentar teu gancho. E assim procedia.

Essa pedagogia pode ser lida também como uma forma de gestão de pessoas, pois, segundo Eloiza da Silva Gomes de Oliveira (2003, p. 55), o grupo produz internamente "um sistema de papéis"; logo, existe, "em qualquer grupo, um permanente jogo de adjudicação e de assunção de papéis”. Mas, quando o líder identifica os papéis e trata-os tendo objetivos que contemplem o grupo, dessa forma, segundo a autora, "[...] à medida que os papéis forem sendo reconhecidos, assumidos e modificados, as pessoas foram adquirindo um senso de sua própria identidade, assim como uma diferenciação com os outros”.

As lideranças que estavam no sindicato nem sempre representavam o pensamento dos trabalhadores: ininterruptamente, 
havia oposição e, muitas vezes, grande parte dos trabalhadores que estavam no cais tinham mais persuasão do que os próprios representantes sindicais. Além disso, havia as lideranças nos gangos, o que dava certo equilíbrio de poder. Maromba cita, por exemplo, que o trabalhador que fazia a distribuição do serviço, que, na maioria das vezes era vice-presidente do sindicato, tinha mais poder que o diretor. Diz ele, como vice-presidente:

[...] lá na beira da praia, o meu poder era tanto ou maior que o do presidente, secretário ou tesoureiro. [...] como fiscal geral está todo o dia em contato com o trabalhador e, se faz um serviço bem feito, tem 70\%, $80 \%$ daquela categoria. Então é uma maneira de tu exercer pressão quando as coisas estão indo mal, tu vens e senta numa mesa de uma diretoria, tu dizes o que está pensando, olha aqui e ali está caminhando errado aqui e ali, e tem que endireitar. Eu não vou falar de novo com vocês, está pegando esse negócio aí, na próxima, eu vou jogar vocês para as feras.

Claudio Batalha (1997, p. 93) divide a militância do movimento operário em três tipos: as lideranças, os quadros intermediários e os militantes de base. $\mathrm{O}$ referido autor caracteriza como liderança uma minoria que escreve em jornais operários e que possui uma "atuação que transcende os limites de sua categoria profissional"; os quadros intermediários são em maior número e se caracterizam por participar "ativamente da vida da categoria, integra direções de associações, assina manifestos, mas raramente escreve sobre sua prática e muito menos produz teoria"; e os militantes de base, numericamente maior, se caracterizam por exercer "uma militância eventual, que são a base de todas as organizações, que estão presentes nos momentos de ascensão dos movimentos e os abandonam nos momentos de refluxo".

Cumpre salientar que não somente aqueles trabalhadores militantes ou não - que tinham uma ideologia definida faziam história, participavam do movimento ou tomavam decisões, mas também aqueles que participavam das assembleias ou exerciam algum tipo de pressão nas lideranças, no trabalho, nos espaços de sociabilidade, nos gangos. 
Por outro lado, as diferenças que ocorrem entre militantes e os demais trabalhadores não invalidam a possibilidade de eles terem algo em comum. Por isso, expõe Batalha (1997, p. 94) que os militantes de base, os eventuais, aqueles que muitas vezes se tornam militantes e apoiadores e aparecem nas fontes "[...] produzidas pelo movimento operário organizado [...] trazem informações sobre a classe operária, trazem informações sobre as classes trabalhadoras, ou seja, se a parte não pode ser tomada pelo todo, há na parte elementos do todo". Dessa forma, pode-se pensar a liderança como representante de grupos de trabalhadores, porém não quer dizer que o líder represente todos os trabalhadores. No caso deste estudo, deve-se pensar o líder como representação dos grupos, dos "gangos", o que implica uma maior discussão quanto aos aspectos reivindicativos. Isso proporciona trocas de ideias e interpretações sobre os acontecimentos, bem como leituras e decisões que caracterizam a experiência desses grupos. Nesses encontros, acabavam ocorrendo discussões e debates sobre os mais diversos assuntos, tanto de trabalho quanto de sociabilidade.

Porém, outro aspecto sobre liderança deve ser analisado, especificamente relacionado ao local de escalação, que era fundamental para o trabalhador. Por isso, segundo Maromba, ele passou a ser uma liderança reconhecida:

[porque] a maioria do pessoal que trabalha em estiva é profissional, é trabalhador e gente que quer a coisa organizada, como esse pessoal das gangs ou gangos, são a minoria, e os teus irmãos, aquele que fez uma para ti, não vai fazer duas, porque ele sabe que não tem perdão, aí tu pegas respeito perante a categoria. Quando fazes isso, dali para frente, és dono da situação, o que tu disseres, eles assinam embaixo. Qualquer assembleia, qualquer coisa, eles brigam e morrem por ti, daí tu viras uma liderança mesmo, porque tu fazes a coisa certa.

Pode-se dizer que a narrativa de Maromba é elucidativa, pois ele afirma fazer a distribuição do trabalho a contento de todos. $\mathrm{O}$ que se destaca nessas narrativas é o aspecto prático e reflexivo que 
aponta para as peculiaridades e especificidades das categorias avulsas. Reflexivo, porque era aprender fazendo, usando as referências que tinha e o que havia sido passado por seu pai.

Em outras histórias narradas pelo entrevistado, aparece uma pedagogia que era adotada pelo seu pai quanto à forma de educação de seus filhos, que, pode-se dizer, também era válida para parte dos trabalhadores. Uma pedagogia do teste e do reforçamento. Dois episódios contados por Maromba demonstram essa questão:

O meu pai, quando entrei aqui (na estiva), em 69, em 70, ele aposentado, trabalhando na sacaria, e um camarada que eu chamava de vô, era lutador também, era Antônio Grande, [...]. Eu saí do exército e entrei para a estiva tinha 22 anos, e, os dois me testando, fazendo o serviço errado. Olhei lá de cima do convés, olha lá os caras, um é o meu pai e outro é o meu avô emprestado... E os dois são muito bons de trabalho, só que eles estavam me testando, e eu pensei, o que será que vou falar para esses caras aí, mas vou falar. Porque eu já vim preparado, cabo do exército por três anos, acostumado a dar ordens, aquela coisa toda. Digo:

- Ô! Estivador! Meu camarada! O que está acontecendo com vocês aí?

- $\mathrm{O}$ quê? O que que é?

- Ô! Mas estão anarquizando o trabalho aí. Vão fazer esse troço direito;

- Não amola rapaz, vai cuidar da tua vida.

- Olha, hem! Bom!

Dei uma caminhada, depois voltei, a mesma coisa. Disse:

- Aqui, hei! Psiu! Não tenho pai, não tenho parente na estiva.

Vou dar uma voltinha de cinco minutos, se voltar e estiver na mesma, estão cortados do serviço. Os dois.

E já eram 4 horas da tarde, saí, quando voltei estava tudo direitinho, porque eles eram bons de trabalho. [...] eles estavam me testando para ver... Para me dizer, aqui não tens pai, não tens irmão, não tens avô, não tens porra nenhuma, faz a tua parte direito, nós te botamos aqui, nós te tiramos daqui. Daqui a pouco eles vão dizer isso para mim. [...] Depois veio esse avô e disse assim: 
- O guri está bom! Nós estava te testando. [...] o vagabundo que não quiser trabalhar corta mesmo, não tem pai aí.

O outro episódio contado por Maromba ocorreu com seu filho mais velho e seu pai:

[...] o meu guri jogava a bola dele, depois vinha para dentro de casa [...]. O meu pai desconfiando dele, porque ficava muito tempo dentro de casa, sabe. Achando que o guri é bicha, coisa e tal, ignorante. Então, ficava provocando o guri, na hora do almoço, na hora não sei do que, [...] enchendo o saco do guri. Aí o guri já tinha uns onze, doze anos, não aguentou mais, se levantou, botou as duas mãos no saco assim...

- Tá aqui o galinha velho, oh! Tá aqui o galinha, viu o galinha...

Quando eu cheguei em casa, [...] daqui a pouco vem o meu pai, me chamava de Bigo:

- Bigo, vou te dizer, o Marco Aurélio tá muito bom... Olha, rapaz! Fiquei chamando ele de galinha, ele fez um barulho aí, pensei que ele ia dar em mim, tá muito bom ele aí. (risos)

Pode-se dizer que era uma pedagogia prática, ou nascida da prática, do trabalho, da vida, do dia a dia, em que os trabalhadores tinham que solucionar problemas, decidir e, como todo o ser humano, passar essa sua forma cultural, costumeira, de solucioná-los, fruto da experiência: ação/reflexão/ação, práxis e consciência.

Retomando a experiência do trabalho avulso, percebe-se a construção de diversas formas de ações coletivas, diversas técnicas que eram passadas de gerações a gerações de estivadores, formas facilitadoras do trabalho. Portanto, dentro dessa linha de raciocínio, para cada tipo de trabalho, havia formas costumeiras de carregar e descarregar que eram usadas, além de técnicas para colocar a carga no navio e possibilitar que ele pudesse navegar sem causar problemas à carga. Jorge Paiva explica o que é estivar, demonstrando que existia uma técnica específica para cada tipo de carga. Destacamos 
que havia necessidade de conhecimento do serviço. Segundo o entrevistado: "[...] estivar é colocar a fileira parelha, que é para o navio equilibrar, não pode ficar o peso maior nem para um lado nem para o outro, [...] quando o navio sair, não ficar com problema. Não pode ficar na proa, nem demais, nem de menos. [...] daí o navio pode singrar normalmente”.

Outra demonstração desses conhecimentos se dá pelo exemplo de como ocorria a descarga de granel: adubo, sal etc. Depois de um determinado período de descarga, quando, primeiro, faz-se um buraco, um poço, que os trabalhadores denominaram de bica, conforme Geraldo da Silveira ${ }^{18}$, em entrevista ao autor:

[...] desceu as caçambas, três homens em cada caçamba, e aí tu vais abrindo em volta, tu botas a caçamba aqui e vai enchendo, botou a caçamba aqui agora tu tiras daqui e bota para lá, tu vais andando com a caçamba em volta, e vais fazendo um poço, um buraco. Quando esse buraco está numa altura - tens de fazer grande para o homem não ficar ali dentro daquele buraco, fazer um lugar que dê para sair, porque, se der qualquer problema, ele pode sair -, tem uma altura, por exemplo, que vai enterrar a caçamba, de um metro e meio, vamos dizer. Aí tu botas a caçamba - a caçamba tinha acho que uns $80 \mathrm{~cm}$ por aí - faz um furo, uma parede, como se fosse aqui, olha: o adubo está todo para lá, e tu vais botar a caçamba de boca aqui, não é isso... Aí, tu fazes um valo naquele adubo, tu fazes uma valinha e uma bica. Aquele valo segue até a caçamba, se o adubo estiver muito mole, tu pegas umas tábuas e cavas assim e bota papelão, aquilo ali vai ficar como se fosse um funil...

Pode-se verificar, além da facilidade que se obtinha na descarga, após fazer a bica, o perigo que corriam, mas, por outro lado, a preocupação com a segurança, em fazer a bica de um tamanho tal que o trabalhador que ficasse embaixo não corresse o perigo.

Com relação à movimentação e arrumação de sacarias, tanto nos armazéns quanto nos porões dos navios, havia de se ter uma combinação entre técnica, jeito e força. Conforme Jorge Paiva, "[...] 
tive a felicidade de conhecer pessoas que muita coisa me ensinou, por mais rude que seja o serviço, tudo tem uma destreza, tudo é por prática e força de vontade. Porque ali o senhor ganhava dinheiro, mas tinha que ter força de vontade". Na movimentação de sacarias, o entrevistado conta como funcionava, "a pessoa tinha que ir pra baixo da tala, pra poder cabecear os sacos de soja, milho, feijão ou arroz. [...] Era de mil e quinhentos, dois mil, a três mil sacos. E tinha que bater aquilo. Tinha a bateria, a bateria era de seis". A bateria era realizada por um conjunto de trabalhadores que se revezavam para chegar até o local onde eram colocados os sacos, formando uma organização de trabalho coletiva de forma ordenada para que não houvesse choque entre os companheiros.

Para Geraldo da Silveira, esse trabalho coletivo, onde "cada um pega na orelha do saco, [...] o arroz era barbadinha, tu mete a mão, depois de tu pegares a prática, faz a orelha dele, pegas o jeito dele, olha tu leva um saco de arroz aonde tu queres”. Para a arrumação ou estivagem da carga, nos armazéns, Jorge Paiva diz que "[...] tinha o pessoal que estava na parte de cima lá, iam pegando e iam colocando até chegar àquela parte assim... até levantar um pouquinho, depois ia tudo por cabeceado pra poder colocar lá em cima”. A estivagem era a amarração da carga, tinham que colocar um conjunto de sacaria na ponta de cada lote de sacos para não cair.

Outro trabalho que era totalmente manual e coletivo era a descarga de tanino. Era imprescindível o uso de técnica e força, porque ficava em espaço de difícil acesso, mas era possível vencer de forma coletiva. A descarga de tanino de uma chata, um saco de cinquenta quilos fazia-se com um número reduzido de três homens. Segundo Jorge Paiva, “[...] nós começávamos, os setecentos e cinquenta sacos, primeiro tinha que abrir... um ficava de cócoras, assim, e puxava o saco até fazer um buraco, e um segurava o pé do outro, assim, para ele puxar; aquilo ali era uma coisa fantástica”.

Outra carga que era inicialmente manual, mas que tinha uma forma de fazer o trabalho render, era a carga de carvão. Edson Sarat de Mello ${ }^{19}$, em entrevista ao autor, relata essa situação. Diz o entrevistado que, no início do trabalho, era totalmente manual, porque 
"[...] o navio vinha com quatro, cinco, seis mil toneladas. Então, ele vinha até em cima dos porões, três ou quatro porões cheios. Para trabalhar, quando estava cheio, trabalhava enchendo com a mão; de luva, ficava enchendo as caçambas à mão". Mas, como o trabalho não dava produção, "[...] não tinha pressa, se tinha que ficar dez dias aí, dez dias ele ia ficar, porque era uma chamada baixa, e como não tinha como andarmos ligeiro, tinha que ser à mão, às vezes com garfo". Mas, quando chegava ao assoalho do navio que aí "[...] rendia bem, quando chegava lá no cobo, aí a gente furava, e a gente trabalhava com a pá, e aí ficava bem melhor de fazer".

Segundo Tiriba (2001, p. 197), "[...] o processo de produção, apropriação e expropriação do conhecimento é uma das mediações nas relações de produção capitalista, ficando a afirmação ou negação do saber do trabalhador determinada pelos interesses do capital". A mobilização dos conhecimentos adquiridos pelos trabalhadores servia ao capital, sendo sua força de trabalho vendida ao dono das mercadorias, que tinham o controle sobre o corpo do trabalhador, à medida que ele se empregava em uma determinada embarcação. A esse fato, pode-se contrapor que as formas de inserção ou não do trabalhador passava pela sua liberdade de poder trabalhar ou escolher o ócio, porém, no reino da necessidade, o trabalho acabava falando mais alto. Por outro lado, algumas alternativas eram conjecturadas pelos trabalhadores, só que acabavam por explorar outros trabalhadores que ainda não eram sócios do sindicato, mas ficavam à espreita por trabalho. 


\section{Considerações finais}

A maior expropriação que o capital realizou foi tirar a forma de organização dos trabalhadores pela experiência, porque, quanto ao emprego da mão de obra, a aprendizagem era na prática, e o trabalho era a forma de ensinamento, a pedagogia do aprender fazendo. No entanto, no final dos anos setenta, têm início algumas mudanças, devido à mecanização, à necessidade de qualificar os trabalhadores como operadores de máquinas e sinaleiros e promover segurança no trabalho. Portanto, daí foi um passo para, posteriormente, mexer no gerenciamento da mão de obra, colocando cursos para as chefias, que acabaram modificando, inclusive, aquelas necessidades iniciais que o sindicato impunha para exercer cargos de chefia, que passaram, porém, não mais pela questão da experiência, de tempo de associado ao sindicato, mas pela valorização de cursos que foram oferecidos pela capitania no final dos anos setenta. Assim, modificou-se de dois e cinco anos, respectivamente para contramestre de porão e contramestre geral, para seis meses, o período de associado e a realização de cursos para cargos de chefia. Conforme relata Edson de Mello, "[...] o pessoal antigo levava dois anos pra fazer chefia, porque tu tinhas que estar muito ciente do que estava fazendo, e saber mandar; no nosso tempo, depois, passou para seis meses". A responsabilidade sobre os trabalhadores do porto era da capitania dos portos, além do sindicato, "[...] todos os estivadores tinham que estar matriculados" na capitania; dessa forma, a capitania tomou para si a responsabilidade pela proposição de diversos cursos, como os de sinaleiro, de operador de máquinas. Segundo Edson de Mello, foram oferecidos cursos "[...] de operador, de estivagem, para saber estivar o porão do navio, a carga de sacaria, [...] colocar sempre direitinho, chamava estivar, não podia ser assim, nem assim. Tinha que fazer as faces, porque, dentro do porão, podiam ir três tipos diferentes de cargas", e, no final dos anos setenta, foi realizado o primeiro curso de mestria, que era para fazer cargos de chefia, pois "[...] os cursos iam até um abaixo do curso de mestria. O primeiro curso de mestria eu fiz, que eram 25 estivadores; eu tive o privilégio de fazer o primeiro curso de mestria, dado pela capitania dos portos, em 1978”.

Anos 90, Porto Alegre, v. 22, n. 42, p. 407-445, dez. 2015 
Portanto, os trabalhadores tinham uma forma peculiar de passar os conhecimentos para as futuras gerações, caracterizando-se em uma pedagogia do trabalho braçal e coletivo, cujas bases estão na priorização dos elementos práticos, cotidianos e costumeiros. Essas construções são fundamentais na constituição da experiência do trabalho e reforçaram a configuração das lutas dos trabalhadores do porto de Porto Alegre, representados pelos seus Sindicatos e Federações.

A interdependência entre os costumes, a memória e o corpo é fundamental para se pensar a história dos trabalhadores do porto de Porto Alegre, pois o conjunto dos corpos individuais dos trabalhadores gerou o corpo social das categorias de trabalhadores braçais, do porto de Porto Alegre. Esses trabalhadores, à medida que se constituem e se constroem com uma identidade somada dos corpos estigmatizados, pela experiência, vivência e relações cotidianas, tomam consciência de sua condição de trabalhador. As imagens presentes na sociedade, pensadas e divulgadas pelos empresários do setor dos transportes, de trabalhadores rudes, sem preparo técnico, com pouco diálogo, que se acertam na porrada, na marra, acabam servindo para a disputa de poder e auxiliaram o capital em suas intenções de desbancar as ações de manutenção do closed shop, dos costumes e dos ganhos dos trabalhadores. Sabiam muito bem os empresários e os agentes do governo que os trabalhadores tinham construído um corpo social muito forte, um corpo que descendia do potencial do trabalho braçal, da união estabelecida pelos trabalhadores, pela capacidade de luta, e que isso só poderia ser vencido, com muita dificuldade, com base na ideologia da modernização dos portos: mecanização, ideal técnico em oposição ao costume, gerenciamento da mão de obra por um organismo não sindical, maior controle dos portos pelos empresários, privatização dos portos e desconstrução do poder dos sindicatos e dos trabalhadores. Por outro lado, os trabalhadores, à medida que se deram conta disso, lutavam pela manutenção de suas formas costumeiras e da legislação que ainda os favoreciam. Todavia, os espaços no porto foram diminuindo, e isso levou aqueles trabalhadores do quadro-extra a serem descartados da inserção no porto de Porto Alegre. Isso gerou e foi gerado pela crescente investida na diminuição da utilização 
da mão de obra e no enfraquecimento dos sindicatos, porém esses trabalhadores buscam alternativas de sobrevivência, de trabalho e renda e de construção de sua história.

\section{PEDAGOGY OF MANUAL AND COLLECTIVE WORK AT THE HARBOUR OF PORTO ALEGRE (1961-1989)}

Abstract: In this article examines some elements of the forms of work organization of the workers in the port of Porto Alegre, in the years 60, 70 and 80 of the twentieth century, mainly focusing on the customary ways how was the process teaching learning of the worker, in work acting, relationships and inter-relationships in everyday life. Action of people in the construction of its history, which is called the pedagogy of manual and collective work. The main sources used are the narratives produced by the interaction between interviewer and interviewee, by recording the oral history, the fruit of the collective experience of port workers, because even with register of individual memories, always representing the community in which it is inserted the narrator. It is perceived by these narratives, collated from other sources, that the longshoreman had a peculiar way of passing knowledge to future generations, whose bases are in prioritizing the practical, everyday and customary elements. These constructs are fundamental in the constitution of experience of work and reinforces the configuration of workers' struggles in the port of Porto Alegre, represented by their unions and federations.

Keywords: Independent Workers. Workers. Manual and Collective Labor. Teaching and Learning.

\section{Notas}

${ }^{1}$ Eduardo RECH: advogado, presidente do sindicato dos conferentes de Porto Alegre desde 1976; Jorge PAIVA: funcionário público do município de Porto Alegre, filiado ao Sindicato dos Arrumadores de Porto Alegre até 1983 e estivador bagrinho dos anos 70 a 80; João ALBINO (Maromba): aposentado, estivador, filiado ao Sindicato dos Estivadores de Porto Alegre desde 1968; Geraldo Mello da SILVEIRA: estivador, arrumador e trabalhador do DEPRC. Conseguiu o vínculo ao DEPRC em 1986. No momento da entrevista encontrava-se aposentado. Edson de Mello, filho de estivador, inicialmente foi funcionário do sindicato, na intervenção de 1964, depois saiu e retornou nos anos setenta, novamente como funcionário do sindicato, vindo a se tornar estivador do quadro em 1976.

Anos 90, Porto Alegre, v. 22, n. 42, p. 407-445, dez. 2015 
Essas entrevistas foram transcritas, revisadas e adequadas à linguagem padrão e fazem parte do acervo do autor.

${ }^{2}$ Grupos de trabalhadores que executam uma determinada tarefa que necessita ser coletiva.

${ }^{3}$ Closed shop é o controle do mercado de trabalho pelos operários sindicalizados. ${ }^{4}$ SPH. Superintendência de Portos e Hidrovias. Porto de Porto Alegre: Apresentação. Disponível em: <http://www.sph.rs.gov.br/sph_2006/content/porto_poa/ porto_poa_apresentacao.php> Acesso em: 19/12/2015.

${ }^{5}$ SPH. Superintendência de Portos e Hidrovias. Porto de Porto Alegre: Zoneamento. Disponível em: <http://www.sph.rs.gov.br/sph_2006/content/porto_poa/ porto_poa_zoneamento.php> Acesso em: 20/12/2015.

${ }^{6}$ Berços são locais onde os navios atracam no cais. Eles têm um fundeio que facilita a atracação.

${ }^{7}$ ANTAQ. Agência Nacional de Transportes Aquaviários. Disponível em: $<$ http://www.antaq.gov.br/portal/pdf/Portos/2012/PortoAlegre.pdf > Acesso em: 20/12/2015.

${ }^{8}$ Calado é o canal por onde trafega o navio até chegar a seu destino, esses canais têm que ser limpos constantemente para possibilitar a navegabilidade e evitar que a embarcação encalhe na areia. O processo de limpeza dos canais é denominado de dragagem.

${ }^{9}$ ANTAQ. Agência Nacional de Transportes Aquaviários. Disponível em: $<$ http:// www.antaq.gov.br/portal/pdf/Portos/PortoAlegre.pdf> Acesso em: 20/12/2015. ${ }^{10}$ PAIVA, Jorge. Jorge Paiva: depoimento [fev. 2008]. Entrevistador: Jairo Luiz Fleck Falcão. Porto Alegre: UNISINOS, 2008. 3 cassetes sonoros. Entrevista concedida ao Projeto História dos Trabalhadores do Porto de Porto Alegre.

${ }^{11}$ ALBINO, João. João Albino, Maromba: depoimento [abr. 2008]. Entrevistador: Jairo Luiz Fleck Falcão. Porto Alegre: UNISINOS, 2008. 6 cassetes sonoros. Entrevista concedida ao Projeto História dos Trabalhadores do Porto de Porto Alegre.

${ }^{12}$ RECH, Eduardo. Eduardo Rech: depoimento [jan. 2008]. Entrevistador: Jairo Luiz Fleck Falcão. Sapucaia do Sul: UNISINOS, 2008. 2 cassetes sonoros. Entrevista concedida ao Projeto História dos Trabalhadores do Porto de Porto Alegre. ${ }^{13}$ Em princípio, a atividade de conferência de carga e descarga obedecia a instruções reguladoras expedidas em cada porto pelos Conselhos Regionais do Trabalho Marítimo. As instruções reguladoras do exercício da profissão de conferente de carga e descarga foram expedidas pelos Conselhos Regionais do Trabalho Marítimos com base no Decreto-Lei no 3.346, de 11/06/1941, Lei no 1.561 , de 16/02/1949, e Decreto no 56.367, de 27/05/65. Este último Decreto gerou uma série de discussões por parte dos Conferentes de Carga e Descarga nos Portos do Rio Grande do Sul. 
${ }^{14}$ Cabia à Delegacia do Trabalho Marítimo - DTM, a regulamentação do trabalho nos portos; no caso específico de Porto Alegre a DTM estava sediada em Rio Grande, mas tinha a Subdelegacia na capital; portanto, na medida em que estava sendo implementada a ditadura militar no país e seu projeto, as DTMs, estavam tomando pé da situação de cada porto, por isso, para o Rio Grande do Sul, tendo como base o que era costumeiro nos portos, o rodízio era imposição legal.

${ }^{15}$ Após horas de debates sobre o assunto, foi aprovado o seguinte Regimento interno para distribuição do trabalho: - art. 1ํㅡㄹ A distribuição do Trabalho será efetuado em rodízio, de modo a satisfazer a necessidade do trabalho proporcionando equitatividade de trabalho e salário aos profissionais participantes de quatro escala, distintas, a saber: a) chefia; b) ajudantes (majoradas); c) rendição e d) portas ou lingadas. Art. $2^{\circ}$ Escalas p/ conferentes chefes: engajamento pelo computo dos valores auferidos (ganho). Art. $3^{\circ}$ Serão escalados a partir da requisição das Entidades Estivadoras permanecendo na função de início ao fim da operação da embarcação; Art. $4^{\circ} \mathrm{O}$ conferente chefe (ou seu substituto) deverá estar presente ao setor de trabalho trinta (30) minutos antes do início de cada período ou turnos, observando rigidamente o art. $16^{\circ}$ das Instituições Reguladoras da Profissão; art. 5o Os erros e deficiências estarão sujeitos: substituição imediata, punição em conformidade com o of. 3/59 de 17.07 .59 a DTM; com devida apreciação pelo Egrégio Conselho da DTM. Art. $6^{\circ}$ Escalas de Ajudantes (majorados) engajamento pelo computo com valores auferidos. (Ata da Assembleia Geral, no 92, 04.02.1965 do Sindicato dos Conferentes de Carga e Descarga do Rio Grande do Sul).

${ }^{16}$ Gango em português e gang em inglês, quer dizer a relação do número de trabalhadores estivadores que estão trabalhando, a organização por ternos e a inserção do trabalho.

${ }^{17}$ Quanto ao operador de guindaste, quando o navio tinha guindaste de bordo, quem operava era o estivador, mas, quando era guindaste de terra, era o portuário. Havia também os "paus de carga" ou guinchos de bordo. Quem os operava era o estivador.

${ }^{18}$ SILVEIRA, Geraldo Mello da. Geraldo Mello da Silveira: depoimento [jun. 2008]. Entrevistador: Jairo Luiz Fleck Falcão. Sapucaia do Sul: UNISINOS, 2008. 182 minutos de gravação digital. Entrevista concedida ao Projeto História dos Trabalhadores do Porto de Porto Alegre.

${ }^{19}$ DE MELLO, Edson Sarat. Edson Sarat de Mello: depoimento [mar. 2009]. Entrevistador: Jairo Luiz Fleck Falcão. Sapucaia do Sul: UNISINOS, 2009. 132 minutos de gravação digital. Entrevista concedida ao Projeto História dos Trabalhadores do Porto de Porto Alegre. 


\section{Referências}

ALBERTI, Verena. Ouvir Contar: Textos em História Oral. Rio de Janeiro: Editora FGV, 2004.

. Histórias dentro da História. In: PINSKY, Carla Bassanezi (Org.). Fontes históricas. São Paulo: Contexto, 2010.

ALBINO, João. João Albino, Maromba: depoimento [abr. 2008]. Entrevistador: Jairo Luiz Fleck Falcão. Porto Alegre: UNISINOS, 2008. 6 cassetes sonoros. Entrevista concedida ao Projeto História dos Trabalhadores do Porto de Porto Alegre.

ARRUDA, José J. de Andrade. Experiência de classe e experimento historiográfico em E. P. Thompson. Projeto História, São Paulo, v. 12, p. 95-107, out. 1995. BATALHA, Claudio H. M. Vida Associativa: por uma nova abordagem da história institucional nos estudos do movimento operário. Anos 90, Porto Alegre, n. 8, p. 91-99, dez. 1997.

BOSI, Ecléia. Memória e Sociedade: Lembranças de Velhos. São Paulo: Companhia das Letras, 2004.

CAMARGO, Aspásia; NUNES, Márcia. Como fazer uma entrevista? Rio de Janeiro: Finep; CPDOC, 1977.

CONSTANTINO, Núncia Santoro de. Teoria da história e reabilitação da oralidade: convergência de um processo. In: ABRAHÃO, Maria Helena Menna Barreto (Org.). A Aventura (auto)biográfica: teoria e empiria. Porto Alegre: EDIPUCRS, 2004.

. Nas entrelinhas da narrativa: vozes de mulheres imigrantes. Estudos Ibero-Americanos, Porto Alegre, v. 32, n. 1, p. 63-73, jun. 2006.

DE MELLO, Edson Sarat. Edson Sarat de Mello: depoimento [mar. 2009]. Entrevistador: Jairo Luiz Fleck Falcão. Sapucaia do Sul: UNISINOS, 2009. 132 minutos de gravação digital. Entrevista concedida ao Projeto História dos Trabalhadores do Porto de Porto Alegre.

HALBWACHS, Maurice. A memória Coletiva. São Paulo: Vértice, 1990.

HARRES, Marluza M. Aproximação entre história de vida e autobiografia: os desafios da memória. História Unisinos, São Leopoldo, v. 8, n. 10, p. 146-147, jul./dez. 2004. 
HOBSBAWM, Eric J. Sindicato Nacional Portuários. In: . Os trabalhadores: Estudos sobre a história do operariado. 1. ed. Rio de Janeiro: Paz e Terra, 1981. FALCÃO, Jairo Luiz Fleck. Cooperação, experiência e sobrevivência: a história dos trabalhadores do Porto Alegre (1961-1989). Tese (doutorado em história)Programa de Pós-Graduação em História. São Leopoldo, 2009.

FORTES, Alexandre. O Direito na Obra de E. P. Thompson. História Social, Campinas, n. 2, p. 89-111, 1995.

LE GOFF, Jacques (Org.). Memória, História. Enciclopédia Einaudi. v. 1. Lisboa: Imprensa Nacional, 1984.

OLIVEIRA, Eloiza da Silva Gomes de. Princípios e métodos de gestão escolar integrada. Coritiba: IESDE, 2003.

PAIVA, Jorge. Jorge Paiva: depoimento [fev. 2008]. Entrevistador: Jairo Luiz Fleck Falcão. Porto Alegre: UNISINOS, 2008. 3 cassetes sonoros. Entrevista concedida ao Projeto História dos Trabalhadores do Porto de Porto Alegre.

PENNA, Rejane Silva. Fontes orais e historiografia: avanços e perspectivas. Porto Alegre: EDIPUCRS, 2005.

RECH, Eduardo. Eduardo Rech: depoimento [jan. 2008]. Entrevistador: Jairo Luiz Fleck Falcão. Sapucaia do Sul: UNISINOS, 2008. 2 cassetes sonoros. Entrevista concedida ao Projeto História dos Trabalhadores do Porto de Porto Alegre.

ROUSSO, Henry. A memória não é mais o que era. In: FERREIRA, Marieta de Moraes; AMADO, Jainaína (Org.). Usos \& abusos da história oral. Rio de Janeiro: Editora da FGV, 1996.

SARTI, Ingrid. Porto Vermelho: Os estivadores Santistas no Sindicato e na Política. Rio de Janeiro: Paz e Terra, 1981.

SCHMIDT, Benito Bisso. Entre a filosofia e a sociologia: matrizes teóricas das discussões atuais sobre história e memória. Estudos Ibero-Americanos, Porto Alegre, v. 32, n. 1, p. 85-97, jun. 2006.

SILVA, Fernando Teixeira da. A carga e a culpa: Os operários das Docas de Santos: Direitos e Cultura de Solidariedade, 1937-1968. Santos: Hucitec, 1995.

. Operários sem patrões: os trabalhadores da cidade de Santos no entreguerras. Campinas: Editora da UNICAMP, 2003.

SILVEIRA, Geraldo Mello da. Geraldo Mello da Silveira: depoimento [jun. 2008]. Entrevistador: Jairo Luiz Fleck Falcão. Sapucaia do Sul: UNISINOS, 2008. 182 minutos de gravação digital. Entrevista concedida ao Projeto História dos Trabalhadores do Porto de Porto Alegre.

Anos 90, Porto Alegre, v. 22, n. 42, p. 407-445, dez. 2015 
SINDICATO DOS CONFERENTES DE CARGA E DESCARGA NOS PORTOS FLUVIAIS DO RIO GRANDE DO SUL. Ata Assembleia Geral, n. 92, 04.02.1965.

SUPERINTENDÊNCIA DE PORTOS E HIDROVIAS. Porto de Porto Alegre. Disponível em: <www.sph.rs.gov.br> Acesso em: 30/01/08.

TIRIBA, Lia. Economia Popular e Cultura do Trabalho: Pedagogia(s) da Produção Associada. Ijuí: Unijuí, 2001.

THOMPSON, Edward P. Costumes em Comum. São Paulo: Companhia das Letras, 1998.

. As Peculiaridades dos ingleses e outros artigos. NEGRO, Antonio Luigi; SILVA, Sergio. Campinas: Unicamp, 2001.

VIVIAN, Diego Luiz. Indústria Portuária Sul-Rio-Grandense: Portos, transgressões e a Formação da Categoria dos Vigias de Embarcações em Porto Alegre e Rio Grande (1956-1964). Dissertação (Mestrado)-Programa de Pós-Graduação em História. Instituto de Filosofia e Ciências Humanas da Universidade Federal do Rio Grande do Sul, Porto Alegre, 2008.

Recebido em: 16/11/2014

Aprovado em: 20/03/2015 